\title{
Equality and the British left: A study in progressive political thought, 1900-64
}

\author{
Ben Jackson \\ Manchester University Press, Manchester, 2007, 304pp., £60.00, \\ ISBN: 978-0719073069
}

Contemporary Political Theory (2010) 9, 353-355. doi:10.1057/cpt.2009.28

There are two stated ambitions in Ben Jackson's monograph, neither of which quite captures the accomplishment of his work. One is to 'deepen our understanding of the ideological influences on Britain's political trajectory in the twentieth century' (p. 1), by providing an analysis of an egalitarian tradition that has been central to our politics, but has, to his mind, been misrepresented. The other is to 'contribute to the history of egalitarian political theory' (p. 1), by demonstrating the significance of British political thought in the development of the concept of equality - thereby countering the tendency to disregard or misrepresent its contribution.

Although these more specific aims are addressed, the more wide-ranging achievement is a nuanced and well-written account of a rich tapestry of egalitarian thought in Britain. One might raise some minor points of criticism: there seems to be an unnecessary anxiety to justify the focus on the period in question, which might be taken to downplay the contribution of earlier thinkers; greater clarification on the relation between political theory and ideology may also have been appropriate. However, the manner in which the ideas of thinkers such as Cole, Tawney and Crosland are interwoven with broader trends, debates and policies - without losing their vivacity or finer distinctions - demonstrates an admirable breadth of scope and economy of expression. It should, as the sleeve suggests, be of great interest to scholars and students of British history and political theory, as well as those interested in contemporary debates. Although the less informed reader may find it difficult to draw out the broader implications of the ideas documented, there is ample stimulation to discover more about British political history and egalitarian political theory.

For those with more specific knowledge, there is much of weight to consider - most especially, I would suggest, for the student of political theory. If there is a tendency for the study of contemporary Anglo-American ideas to begin and end with 'the Rawls industry', here is a welcome antidote. Jackson 
himself occasionally draws out the parallels between many of the core ideas of equality under discussion and staples of the Rawlsian lexicon. For those versed in contemporary liberal egalitarianism, it is striking how the book reveals that present debates have already been played out - in a less cerebral manner, and sadly, a more sympathetic era.

The book is divided up both chronologically and thematically: Part I takes the period from the turn of the century to 1931, emphasising the relative consensus on the left. The first chapter analyses the progressives' rejection of meritocracy and their emphasis on ideas of 'fellowship'. Chapters II and III chart the development of their normative arguments and practical implications of these debates. The notion that the poor held a claim of justice to resources - on the basis of their contribution - was supplemented by the belief that equality should allow people to fulfil their social function. The more 'applied' aspects of progressive debate focused upon the efficacy of outcome equality, the importance of meeting needs and the justifiability of incentives.

Part II examines the period from 1931 to 1945 , when in the face of the depression and the implosion of the Labour Party, a chasm emerged on the left between what can be crudely described as Marxists and Keynesians. In Chapter IV, Jackson concludes that despite the short-lived prominence of historical materialism on the British left, and the eventual reconciliation with the 'idealism' of more traditional ethical socialism, the questioning of the efficacy of gradualism and the possibility of socialism in a capitalist economy were to have a longer term influence. In the following chapter, Jackson recounts the manner in which the less radical left turned to Keynesian and utilitarian ideas to argue that socialism was conducive to an efficient and productive society egalitarianism 'mandated by science' (p. 128). The debates surrounding the socialisation of the economy, the extent and means of redistribution, and importance of fellowship to the socialist project, were outstanding issues, their resolution put on hold by the war.

The final part of the book documents the manner in which these conflicts came to a head in the post-war debates between the revisionists, Bevanites and emerging groups such as the New Left. It may, in some sense, be read as a defence of the egalitarian pedigree of the revisionists, and it is notable that Jackson plays down the 'overrated Bevanite/Gaitskellite debate' (p. 164). However, in the final chapter he identifies the major departure from more traditional socialist thought in the revisionist programme epitomised by Crosland's work - the disregard for the doctrine of fellowship. Charting the influence of this revisionist turn would be the work of another chapter for Jackson. In conclusion, however, he is content to leave us with a sobering message. If one touchstone of British egalitarian thought fell into neglect following the war, he asks what we should make of a political left

354 (C) 2010 Macmillan Publishers Ltd. 1470-8914 Contemporary Political Theory Vol. 9, 3, 345-355 
that loses sight of its definitive founding principle: 'For if the Left does not strive to narrow economic and social inequality, and to tackle the multiple injustices of a class-riven society, then in what sense does it remain "the Left"?'

Huw Williams

University of Aberystwyth, UK 